\title{
STUDY OF SPONTANEOUS CRYSTALLURIA ON A SERIES OF PATIENTS IN THE TADLA AZILAL MOROCCAN AREA.
}

\author{
M. Mbarki, A. Oussama, A. Elbouadili', A. Semmoud², M Berkani, M. Touhami and A. J. \\ Jabrane ${ }^{3}$.
}

Laboratory of spectrochemistry and environment, Beni Mellal Faculty of Sciences and Technologies.

Beni Mellal-Morocco.

'Scientific research center, Beni Mellal Faculty of Sciences and Technologies. Beni Mellal-Morocco.

2Laboratory of Infrared- and Raman-Spectrochemistry, LASIR, CNRS UMR, Building C5, Lille University of Sciences et Technologies, Villeneuve d'asca Cedex, France.

3Jabrane Clinic, 23000 Beni Mellal-Morocco.

\begin{abstract}
Summary.- OBJECTIVES: There are few studies on crystalluria in the developing countries. The aim of the present study was carrying out a first study in Morocco on the frequency and the chemical nature of the crystalluria according to the sex and the age of human individuals living in the Tadla Azilal moroccan area.
\end{abstract}

METHOD: 200 samples resulting from the morning urines of morning fasting individuals of the two sexes and different ages were collected. The $\mathrm{pH}$ was measured by a portable $\mathrm{pH}$-meter "Pocket $\mathrm{pH}$-meter ad $110 \mathrm{pH}$ ".

The identification of the chemical nature of the crystalluria was carried out using a polarized light microscope "Olympus BX41". Such identification was based on morphology, polarization, and the $\mathrm{pH}$ of the urinary crystals.
RESULTS: In this series the positive frequency of crystalluria was $25.4 \%$ and was distributed on 3 age groups so that $27.9 \%$ in the youngest group, $32.6 \%$ in the middle aged group and $39.5 \%$ in the oldest one. The distribution on the sex is such as $53.4 \%$ in the man and $46.5 \%$ in the woman. A large majority (83.7\%) of the crystalluria consists of homogeneous crystalluria. In the man, the Weddellite is dominant (69.6\%) in the crystalluria while in the woman the Weddellite yields the place to the two phases of the uric acid (60\%).

CONCLUSIONS: The studied series presents a non high frequency of crystalluria, which increases with the age. The factor sex has weakly increased the frequency of crystalluria in the man compared to the woman. The oxalocalcic nature is dominant in the crystalluria resulting from the man while it is the uric nature that is so in the woman. Other studies are necessary to be able to understand the etiology of a such difference, in the chemical nature of the crystalluria, between the two sexes.

Keywords: Crystalluria. Frequency. Weddellite. Whewellite. Uric acid. Calcic phosphates complex. Amorphous urate complex.

Resumen.- OBJETIVO: Hay pocos estudios sobre la cristaluria en países en desarrollo. El objeto de este estudio fue llevar a cabo un primer estudio en Marruecos sobre la frecuencia y la naturaleza química de la cristaluria de los habitantes de la zona de Tadla Azilal en función del sexo y la edad. 
MÉTODOS: Se recogieron 200 muestras de orina de la primera micción de la mañana de individuos en ayunas de ambos sexos y diferentes edades. Se midieron pHs con un medidor de $\mathrm{pH}$ portátil "Pocket pHmeter ad 110 pH". La identificación de la naturaleza química de la cristaluria se llevó a cabo utilizando un microscopio de luz polarizada Olympus BX4 1. La identificación se basó en la morfología, la polarización y el pH de los cristales urinarios.

RESULTADOS: En esta serie, la frecuencia de cristaluria fue de $25,4 \%$ y se distribuía en tres grupos de edad, con $27,9 \%$ en el grupo más joven, $32,6 \%$ en el grupo de edad media y $39,5 \%$ en el grupo de mayor edad. La distribución por sexos fue de $53,4 \%$ en varones y $46,5 \%$ de mujeres. Una gran mayoría $(83,7 \%)$ de la cristaluria era cristaluria homogénea. En el varón la cristaluria dominante es la de oxalato cálcico (weddelita) $(69,6 \%)$, mientras que en la mujer cede el puesto a las dos fases de ácido úrico (60\%).

CONCLUSIONES: Las serie del estudio no presentan una frecuencia elevada de cristaluria, aunque aumenta con la edad. La frecuencia de cristaluria aumenta levemente en el hombre en comparación con la mujer. El oxalato cálcico domina en la cristaluria del varón mientras que el ácido úrico lo hace en la mujer. Se necesitan otros estudios para poder entender la etiología de la diferente naturaleza de la cristaluria entre sexos.

Palabras clave: Cristaluria. Frecuencia. Weddelita. Whewelita. Complejo de fosfatos cálcicos. Complejo de uratos amorfos.

\section{INTRODUCTION}

The spontaneous crystalluria is a risk factor among several which enter in competition to develop the urinary lithiasis disease. Although the polarized light microscopy (PLM) can be useful to study the spontaneous crystalluria it is not sufficiently exploited by as well the scientific re searchers as the clinicians. A simple and fast observation by the PLM, as a first diagnosis, can however provide an useful information for the comprehension of the aetiologies. A Such comprehension can allow the prevention and the therapeutic follow-up of the lithiasis, especially in serious cases like the cystinic lithiasis one.

This case is due to an hereditary tubulopathy characterized by a defect of the proximale tubular reabsorp- tion of the dibasic amino acids. So, the urinary excretion of cystine increases.

\section{PRESENTATION}

Only a few former studies were interested in the correlation between urinary calculi on the one hand and urinary crystals on the other hand $(1,2)$. In the lithiasic patients, such a correlation was showed for chemical species of crystalluria (1).

In Morocco no study of crystalluria was carried out. In the present work, on 200 human patients living the Tadla Azilal moroccan area we studied the chemical composition of the spontaneous crystalluria by means of the PLM, considering the morphology of the urinary crystals, their polarization and the urinary $\mathrm{pH}$.

\section{MATERIEL AND METHOD}

The adult patients (âge> 15 years) constitute a series of 82 men and 87 women. The patients having age that not exceed 15 years are considered children. The samples were collected in sterilized special bottles. By a polarized light microscope "Olympus BX41" we carried out an identification of crystalluria within a time not exceeding an hour after the collection of urine. The expression of the results according to the protocol is described in a work of Daudon and al. [3]. The allowed definition for the crystalluria of an urinary sample is such as if it appears at least a crystal in the conventional grid known as Malassez's cell, the sample is considered as presenting a positive spontaneous crystalluria.To simplify, we imply in the present work, by "crystalluria" and "spontaneous crystalluria" a positive spontaneous crystalluria.

\section{RESULTS}

Results of the 31 children will be developed in a later work concerning the crystalluria of the child. The average urinary $\mathrm{pH}$, on the whole series, is 5.8 as well in the man as in the woman.

\section{A- Age and sex as parameters in the population}

Among the 169 adult patients constituting the series there are 82 men and 87 women with respective percentages of $48.5 \%$ and $51.5 \%$. The age gamut of the patients is so that 16 to 80 years for the man and 16 to 63 years for the woman. The average age is 38 years including 33,1 years in the man case and 42,6 years in the women case. We distributed the patients in three age groups. The youngest group $(15<$ age $\leq$ 
28 years), the middle aged group ( $28<$ age $\leq 40$ years) and the oldest one ( 40 years< age). Table I gives the distribution of the patients of the series on the two sexes and the age groups. In the results Tables of the present work, the numbers between brackets are numbers of patients (Table I) or numbers of crystalluria (Tables II - IV).

\section{B- Frequency of crystalluria}

The number of the crystalluria in the population is 43 including 23 in the men and 20 in the women. Thus, the total frequency of crystalluria in the population is $25.4 \%$. The distribution according to the age and the sex of the frequency of the crystalluria is illustrated by Table II. It is distributed on the two sexes so that $53.5 \%$ in the man and $46.5 \%$ in the woman.

\section{C- Homogeneity of the crystalluria}

The homogeneous crystalluria, i.e with only one component, represents a large majority of the 43 crystalluria in the series. The number of the heterogeneous crystalluria, i.e. with more than one component, is only 7. Table III shows six associations between components met in the heterogeneous crystalluria.

We identify usual urinary crystalline species like the calcium oxalate monohydrated, known as Whewellitte (Wh), and the calcium oxalate dehydrated, known as Weddellite (Wd). There is also amorphous urate complex (AUC), the carbonated calcium amorphous phosphate (CCAP), the two phases of the uric acid (UA2 and
UAO) and the Brushite (Bru). By considering only one majority component in each crystalluria Tables IV and V illustrate, respectively in the man and in the woman, the frequency of the majority component of the crystalluria in each age group.

\section{DISCUSSION}

In the studied series as well the male invidials as the females were volunteers to be subject for the urines collection. The average age of the men is lower than that of the women. This can be explained by cultural and social reasons. In fact the men, in the area place of the present work, have occupations related to the household responsibilities at the time of the morning urines collection.

By distributing the patients on the three selected age groups we observe through table I that almost three quarters of the patients are shared, equitably, between the youngest and oldest groups. Thus a quarter is in the middle aged group.

A quarter of the series (Table II) presents the crystalluria as a risk factor among others (environmental, dietetic, hereditary, genetic, etc...) which contribute to develop the urinary lithiasis disease. According to table II the frequency of crystalluria is distributed in the youngest group, on the two sexes, so that the ratio of the number of the crystalluria resulting from the man to that resulting from the woman is 11.1 . In the middle aged

TABLE I. DISTRIBUTION OF THE PATIENTS ACCORDING TO THE SEX AND THE AGE GROUP.

\begin{tabular}{|c|c|c|c|c|}
\hline & $\begin{array}{c}\text { Percentage of } \\
\text { the men } \\
M\end{array}$ & $\begin{array}{c}\text { Percentage of the } \\
\text { women } \\
\text { W }\end{array}$ & $\begin{array}{c}\text { Total percentage } \\
\text { by age group }\end{array}$ & $\begin{array}{c}\text { Patients ratio }= \\
(\mathrm{M} / \mathrm{W}) \mathrm{pt}\end{array}$ \\
\hline $15<$ age $\leq 28$ years & 45 & 20 & 65 & 2.3 \\
$(26.6)$ & 14 & $(11.8)$ & $(38.4)$ & 0.5 \\
\hline $28<$ age $\leq 40$ years & $(8.3)$ & $(16)$ & $(24.3)$ & 0.6 \\
\hline 40 years< age & 23 & 40 & 63 & $(37.3)$ \\
\hline Total percentage & 82 & $(13.6)$ & $(23.7)$ & 169 \\
by gender & $(48.5)$ & $(51.5)$ & $(100)$ & 0.9 \\
\hline
\end{tabular}


TABLE II. DISTRIBUTION OF THE FREQUENCY OF THE CRYSTALLURIA ACCORDING TO THE AGE GROUP AND THE SEX OF THE PATIENT.

\begin{tabular}{|c|c|c|c|c|c|}
\hline & $\begin{array}{c}\text { Frequency in } \\
\text { the man }\end{array}$ & $\begin{array}{c}\text { Frequency in the } \\
\text { woman }\end{array}$ & $\begin{array}{c}\text { Total frequency by } \\
\text { age group }\end{array}$ & $\begin{array}{l}\text { Frequencies ratio } \\
\qquad(\mathrm{M} / \mathrm{W}) \mathrm{fr}\end{array}$ & $\begin{array}{l}\{(M / W) f r / \\
(M / W) p t\}\end{array}$ \\
\hline $15<$ age $\leq 28$ years & $\begin{array}{l}25.6 \\
(11)\end{array}$ & $\begin{array}{l}2.3 \\
(1)\end{array}$ & $\begin{array}{l}27.9 \\
(12)\end{array}$ & 11.1 & 4.8 \\
\hline $28<$ age $\leq 40$ years & $\begin{array}{l}13.9 \\
(6)\end{array}$ & $\begin{array}{l}18.6 \\
(8)\end{array}$ & $\begin{array}{l}32.5 \\
(14)\end{array}$ & 0.7 & 1.4 \\
\hline 40 years $<$ age & $\begin{array}{l}13.9 \\
(6)\end{array}$ & $\begin{array}{l}25.6 \\
(11)\end{array}$ & $\begin{array}{l}39.5 \\
(17)\end{array}$ & 0.5 & 0.8 \\
\hline $\begin{array}{c}\text { Total frequency by } \\
\text { gender }\end{array}$ & $\begin{array}{l}53.4 \\
(23)\end{array}$ & $\begin{array}{l}46.5 \\
(20)\end{array}$ & $\begin{array}{l}99.9 \\
(43)\end{array}$ & 1.1 & 1.2 \\
\hline
\end{tabular}

group this ratio $(M / W)$ fr falls to 0.7 to reach the value 0.5 in the oldest group. This decrease seems to be in correlation with the evolution of the ratio $(M / W)$ pt of the number of the men to that of the women (Table I). A 2.1 value was recorded for the ratio of the number of urinary calculi resulting from the man to that resulting from the woman in a work of our research team (4). Moreover, in the present work, the factor $\{(M / W)$ fr / (M/W) pt passes to the lower value 0.8 beyond the 40-years age. Such result is concordant with those in former studies $(4,5)$ which reported that the renal lithiasis affects the adult between the 20- and 60-years age. In this context we report that it has been allowed that the maximum risk to develop an urinary calculi is around 40 years (6).

\section{TABLE III. DISTRIBUTION OF THE FREQUENCY OF THE ASSOCIATIONS IN THE HETEROGENEOUS CRYSTALLURIA.}

\begin{tabular}{|c|c|c|}
\hline Association & Number & Frequency $\%$ \\
\hline $\mathrm{Wh}+\mathrm{Wd}$ & $(2)$ & 28,6 \\
\hline $\mathrm{Wd}+\mathrm{AUC}$ & $(1)$ & 14.3 \\
\hline $\mathrm{Wh}+\mathrm{AUC}$ & $(1)$ & 14.3 \\
\hline $\mathrm{Wd}+\mathrm{CCAP}$ & $(1)$ & 14.3 \\
\hline $\mathrm{AUC}+\mathrm{UAO}$ & $(1)$ & 14.3 \\
\hline $\mathrm{Wd}+\mathrm{Bru}$ & $(1)$ & 14.3 \\
\hline
\end{tabular}

In the present series, according to 1.2 as a total value of the factor $\{(M / W)$ fr / (M/W) pt\} (Table II) the sex seems to play a role in the frequency of crystalluria. Thus the man tends to present higher frequencies than those in the woman. The tendency of the man to present urinary calculi more than the woman (4) was confirmed for the patients not exceeding the 40-years age.

We observe a decrease of the frequency of crystalluria in the man while passing from the youngest age group to the oldest one. This decrease is counterbalanced by an increase in the frequency in the woman.

Only 7 of 43 are heterogegeous crystalluria (Table III). No affinity to association is detected between the chemical cristallines species in the heterogeneous crystalluria. The fact that the great majority of the crystalluria (36 of 43 ) is homogeneous crystalluria allows us to think that probably the studied patients are in a relatively non high state of risk since it is almost characterized by an absence of a second crystalline species, and since the urinary calculi consist frequently of more than one component (4).

In the man Wd is the most frequent major constituent (table IV). This was expected since the calcic lithiasis is the most widespread urinary lithiasis in the world. In the woman, AUC dominates before the 40-years age (table V), however this predominance is attenuated after such age since it is shared, equitably, with UA2 and Wd.

It is known (7) that when the urinary $\mathrm{pH}$ does not exceed 5 the whole uric acid (UrAc) crystallizes in 
TABLE IV. FREQUENCY OF THE MAJORITY COMPONENT ACCORDING TO THE AGE GROUP IN THE MAN.

\begin{tabular}{|c|c|c|c|c|c|c|c|}
\hline \multirow[t]{2}{*}{ Age group } & \multirow{2}{*}{$\begin{array}{l}\text { Total number by } \\
\text { chemical species }\end{array}$} & \multicolumn{2}{|c|}{ Calcic oxalates } & \multicolumn{2}{|c|}{ Uric acid } & \multicolumn{2}{|c|}{ Calcic phosphates } \\
\hline & & $\begin{array}{c}\mathrm{Wh} \\
\%\end{array}$ & $\begin{array}{c}\text { Wd } \\
\%\end{array}$ & $\begin{array}{c}\text { UA2 } \\
\%\end{array}$ & $\begin{array}{c}\text { AUC } \\
\%\end{array}$ & $\begin{array}{c}\text { Bru } \\
\%\end{array}$ & $\begin{array}{c}\operatorname{Str}^{*} \\
\%\end{array}$ \\
\hline $15<$ age $\leq 28$ years & $\begin{array}{l}47.8 \\
(11)\end{array}$ & - & $\begin{array}{l}81.8 \\
(9)\end{array}$ & & $\begin{array}{l}9.1 \\
\text { (1) }\end{array}$ & - & $\begin{array}{l}9.1 \\
(1)\end{array}$ \\
\hline $28<$ age $\leq 40$ years & $\begin{array}{c}26.1 \\
(6)\end{array}$ & $\begin{array}{l}16.7 \\
11)\end{array}$ & $\begin{array}{c}33.3 \\
(2)\end{array}$ & $\begin{array}{l}16.7 \\
(1)\end{array}$ & $\begin{array}{l}16.7 \\
11)\end{array}$ & $\begin{array}{l}16.7 \\
\text { (1) }\end{array}$ & - \\
\hline 40 years $<$ age & $\begin{array}{c}26.1 \\
(6)\end{array}$ & - & $\begin{array}{c}83.3 \\
(5)\end{array}$ & - & - & $\begin{array}{l}16.7 \\
(1)\end{array}$ & - \\
\hline Total by age group & $\begin{array}{l}100 \\
(23)\end{array}$ & $\begin{array}{l}4.3 \\
(1)\end{array}$ & $\begin{array}{l}69.6 \\
(16)\end{array}$ & $\begin{array}{l}4.3 \\
\text { (1) }\end{array}$ & $\begin{array}{l}8.7 \\
(2)\end{array}$ & $\begin{array}{l}8.7 \\
(2)\end{array}$ & $\begin{array}{l}4.3 \\
(1)\end{array}$ \\
\hline \multicolumn{2}{|c|}{ Total by chemical family } & \multicolumn{2}{|c|}{$\begin{array}{l}73.9 \\
(17)\end{array}$} & \multicolumn{2}{|c|}{$\begin{array}{l}13 \\
(3)\end{array}$} & \multicolumn{2}{|c|}{$\begin{array}{l}13 \\
(3)\end{array}$} \\
\hline
\end{tabular}

*Str : Struvite

TABLE V. FREQUENCY OF THE MAJORITY COMPONENT ACCORDING TO THE AGE GROUP IN THE WOMAN.

\begin{tabular}{|c|c|c|c|c|c|c|c|c|}
\hline \multirow[t]{2}{*}{ Age group } & \multirow{2}{*}{$\begin{array}{l}\text { Total number by } \\
\text { chemical species }\end{array}$} & \multicolumn{2}{|c|}{ Calcic oxalates } & \multicolumn{3}{|c|}{ Uric acid } & \multicolumn{2}{|c|}{ Calcic phosphates } \\
\hline & & $\begin{array}{l}\text { Wh } \\
\%\end{array}$ & $\begin{array}{l}\text { Wd } \\
\%\end{array}$ & $\begin{array}{c}\text { UA2 } \\
\%\end{array}$ & $\begin{array}{l}\text { UAO } \\
\%\end{array}$ & $\begin{array}{c}\text { AUC } \\
\%\end{array}$ & $\begin{array}{c}\text { CCAP } \\
\%\end{array}$ & $\begin{array}{l}\text { Str } \\
\%\end{array}$ \\
\hline $15<$ age $\leq 28$ years & $\begin{array}{l}5 \\
(1)\end{array}$ & - & - & - & - & $\begin{array}{l}100 \\
(1)\end{array}$ & - & - \\
\hline $28<$ age $\leq 40$ years & $\begin{array}{l}40 \\
(8)\end{array}$ & - & $\begin{array}{l}12.5 \\
\text { (1) }\end{array}$ & $\begin{array}{l}12.5 \\
\text { (1) }\end{array}$ & $\begin{array}{l}12.5 \\
\text { (1) }\end{array}$ & $\begin{array}{l}50 \\
(4)\end{array}$ & - & $\begin{array}{l}12.5 \\
(1)\end{array}$ \\
\hline 40 years $<$ age & $\begin{array}{l}55 \\
\text { (11) }\end{array}$ & (1) & $\begin{array}{c}27.3 \\
(3)\end{array}$ & $\begin{array}{c}27.3 \\
(3)\end{array}$ & & $\begin{array}{c}27.3 \\
(3)\end{array}$ & $\begin{array}{l}9.1 \\
\text { (1) }\end{array}$ & \\
\hline Total by age group & $\begin{array}{l}100 \\
(20)\end{array}$ & $\begin{array}{l}5 \\
\text { (1) }\end{array}$ & $\begin{array}{l}20 \\
(4)\end{array}$ & $\begin{array}{l}20 \\
(4)\end{array}$ & $\begin{array}{l}5 \\
(1)\end{array}$ & $\begin{array}{l}40 \\
(8)\end{array}$ & $\begin{array}{l}5 \\
(1)\end{array}$ & $\begin{array}{l}5 \\
(1)\end{array}$ \\
\hline \multicolumn{2}{|c|}{ Total by chemical family } & & $\begin{array}{l}25 \\
(5)\end{array}$ & & $\begin{array}{l}65 \\
113\end{array}$ & & & \\
\hline
\end{tabular}


an acid form whereas $95 \%$ of the acid are in an ionized form like ACU when the $\mathrm{pH}$ exceeds this value. This can explain, in the present series, (Table VI) the total frequency $(23.3 \%)$ of AUC (10 of 43 ) and $13.9 \%$ of the uric acid (UrAc) (6 of 43 ) in second and third position, respectively, after Wd in first position (46.5\%: 20 of 43 ) since the average urinary $\mathrm{pH}$ is 5.8 overall. Furthermore, a high uraturie is a risk factor of the calcic lithiasis.

We observe that, contrary to the man, the woman presents a dominance of the uric acid. A sensitivity to UrAc, in the woman more than in the man was already highlighted in a former work (8) on urinary calculi of diabetic patients in France. A relative exposure in the woman more than in the man to UrAc, also, is detected in one of our works, on another series of patients having other characteristic parameters (9). Moreover, various former and recent works have reported that the uric urinary lithiasis can concern as well isolated cases (10, 11 ) as a true tendency in the chemical composition of calculi $(12,13)$.

This does not exclude other factors that directly influence the crystalluria, especially the insufficient hydrous contribution. In fact a recent work on lithiasic patients in Algeria (14) showed the effectiveness of a raised diuresis on the spontaneous expulsion of calculi, the urinary $\mathrm{pH}$, and the crystalluria.

Contrary to $\mathrm{Wd}$ case, the frequency of Wh as a majority constituent is weak, in the two sexes. This tendency known in the case of the crystalluria is frequently reversed in the case of the urinary calculi (15). It can be explained, while passing from the crystalluria to calculation, by the conversion of the calcium oxalate from its dihydrated phase to its monohydrated phase (4), losing a water molecule. In the present work, the crystalluria of Struvite (Str) and the CCAP, as a majority constituent presented weak frequencies in the two sexes. This was expected, comparing to the conventional chemical composition of human calculi.

\section{CONCLUSION}

Compared to the lithiasic individuals, the studied population presents an usual frequency of crystalluria for human individuals suffering of no disease related to the urinary crystals.

The present work showed that globally in the whole series (Table VI) the risk to present a crystalluria

TABLE VI. FREQUENCY OF THE MAJORITY COMPONENT ACCORDING TO THE AGE GROUP GLOBALLY ON THE SERIES.

\begin{tabular}{|c|c|c|c|c|c|c|c|c|c|}
\hline \multirow[t]{2}{*}{ Age group } & \multirow{2}{*}{$\begin{array}{l}\text { Total number by } \\
\text { chemical species }\end{array}$} & \multicolumn{2}{|c|}{ Calcic oxalates } & \multicolumn{3}{|c|}{ Uric acid } & \multicolumn{3}{|c|}{ Calcic phosphates } \\
\hline & & $\begin{array}{l}\text { Wh } \\
\%\end{array}$ & $\begin{array}{l}\mathrm{Wd} \\
\%\end{array}$ & $\begin{array}{c}\text { UA2 } \\
\%\end{array}$ & $\begin{array}{l}\text { UAO } \\
\%\end{array}$ & $\begin{array}{c}\text { AUC } \\
\%\end{array}$ & $\begin{array}{c}\text { CCAP } \\
\%\end{array}$ & $\begin{array}{l}\text { Str } \\
\%\end{array}$ & $\begin{array}{c}\text { Bru } \\
\%\end{array}$ \\
\hline $15<$ age $\leq 28$ years & $\begin{array}{l}27.9 \\
(12)\end{array}$ & - & $\begin{array}{l}75 \\
\text { (9) }\end{array}$ & - & - & $\begin{array}{l}16.7 \\
(2)\end{array}$ & - & $\begin{array}{l}8.3 \\
\text { (1) }\end{array}$ & - \\
\hline $28<$ age $\leq 40$ years & $\begin{array}{l}32.6 \\
(14)\end{array}$ & $\begin{array}{l}7.1 \\
(1)\end{array}$ & $\begin{array}{c}21.4 \\
(3)\end{array}$ & $\begin{array}{l}14.3 \\
(2)\end{array}$ & $\begin{array}{l}7.1 \\
\text { (1) }\end{array}$ & $\begin{array}{r}35.7 \\
(5)\end{array}$ & - & $\begin{array}{l}7.1 \\
\text { (1) }\end{array}$ & $\begin{array}{l}7.1 \\
\text { (1) }\end{array}$ \\
\hline 40 years $<$ age & $\begin{array}{l}39.5 \\
(17)\end{array}$ & $\begin{array}{l}5.9 \\
(1)\end{array}$ & $\begin{array}{c}47.1 \\
(8)\end{array}$ & $\begin{array}{l}17.6 \\
(3)\end{array}$ & - & $\begin{array}{l}17.6 \\
(3)\end{array}$ & $\begin{array}{l}5.9 \\
\text { (1) }\end{array}$ & - & $\begin{array}{l}5.9 \\
\text { (1) }\end{array}$ \\
\hline Total by age group & $\begin{array}{l}100 \\
(43)\end{array}$ & $\begin{array}{l}4.6 \\
(2)\end{array}$ & $\begin{array}{l}46.5 \\
(20)\end{array}$ & $\begin{array}{l}11.6 \\
(5)\end{array}$ & $\begin{array}{l}2.3 \\
\text { (1) }\end{array}$ & $\begin{array}{l}23.3 \\
(10)\end{array}$ & $\begin{array}{l}2.3 \\
(1)\end{array}$ & $\begin{array}{l}4.6 \\
(2)\end{array}$ & $\begin{array}{l}4.6 \\
(2)\end{array}$ \\
\hline \multicolumn{2}{|c|}{ Total by chemical family } & \multicolumn{2}{|c|}{$\begin{array}{l}51.1 \\
(22)\end{array}$} & \multicolumn{3}{|c|}{$\begin{array}{l}37.2 \\
(16)\end{array}$} & \multicolumn{2}{|c|}{$\begin{array}{l}11.5 \\
(5)\end{array}$} & \\
\hline
\end{tabular}


would be beyond the 40-years age whereas this is not confirmed in the man. This result is in correlation with those of former works which have shown a peak to be able to present an urinary calculus between the 40 - and 60 -years age. The ratio of the frequency of crystalluria resulting from the man to that resulting from the woman, in the series, confirmed the tendency known in the man more than in the woman; being able to develop an urinary calculi. The lithogeneous state of crystalluria was characterized by a raised homogeneity frequency compared to that known in the case of the calculi, since these are frequently heterogeneous.

In the man the crystalluria has a weddellitic tendency whereas in the woman the tendency is uric. The sensitivity of the woman with respect to the uric acid forms as a majority component of crystalluria involves that we seek its etiologies by exploiting results of various work, on series of lithiasic populations in the world, which presented a certain tendency to the uric lithiasis.

All in all, the results of this work on the crystalluria in an ordinary population have shown a crystalluria supporting, mainly, the calcic lithiasis which is commonly known as the most frequent lithiasis in the world in the human induviduals. They have also exposed an uric character of the crystalluria, in the woman.

Therefore, other studies, of urinary cristalluries and calculi, are necessary to confirm if, in the present series, it was a really new tendency in the chemical nature of the crystalluria or there were other factors that have occasionally expressed the uric character, in the woman.

\section{REFERENCES AND RECOMENDED READING}

\section{( ${ }^{*}$ of special interest, ${ }^{* *}$ of outstanding interest)}

**1. KAID-OMAR, Z.; DAUDON, M.; ATTAR, A. et al: "Corrélation entre cristalluries et composition des calculs". Progrès en urologie; 9: 633. 1999.

2. DAUDON, M.; JUNGRS, P.; LACOUR, B.: "Intérêt clinique de l'étude de la cristallurie". Ann Biol Clin ; $62: 379.2004$
**3. DAUDON, M.: "Cristallurie: aspects pratiques et interprétation. Première partie: aspects pratiques". Feuillets de biologie; VolXXVIII, N 155: 25. 1987

*4. OUSSAMA, A.; KZAIBER, F.; MERNARI, B. et al: "Analyse des calculs urinaires de l'adulte dans le moyen Atlas Marocain par spectroscopie infrarouge à transformée de Fourier. Progrès en Urologie; 10: 404. 2000.

5. DAUDON, M. et JUNGERS, P.: "Epidémiologie de la lithiase urinaire". L'Eurobiologiste Juin; 253: 5. 2001.

6. JUNGERS, P.: "Epidémiologie de la lithiase urinaire. In: Jungers P, Daudon M, Le Duc A. Lithiase urinaire. Paris. Flammarion Médecine-sciences: 1. 1989

7. PAK, C.Y.C.; SAKHAEE, K.; PETERSON, R.D.: "Biochemical profile of idiopathic uric acid nephrolithiasis”. Kidney In.; 60: 60. 2001.

8. DAUDON, M.; JUNGERS, P.: "Diabète et calcul". Feuillets de biologie; Vol. XXXXII, $\mathrm{N}^{\circ}$ 239: 37. 2001.

*9. MBARKI, M.; OUSSAMA, A.; DAUDON, M.: "Cristallurie de patients diabétiques". Progres en Urol.; 15:420. 2005.

10. GARCÍA-PAVÍA, P.; TORRES, R.J.; RIVERO, M. et al.: "Phosphoribosylpyrophosphate synthetase overactivity as a cause of uric acid overproduction in a young woman”. Arthritis Rheum Jul; 48: 2036. 2003.

11. SIENER, R.; HESSSE, A.: "The effect of a vegetarian and different omnivorous diets on urinary risk factors for uric acid stone formation”. Eur. J. Nutr. Dec; 42: 332. 2003.

12. HOSSAINE, R.Z.; OGAWA, Y.; HOKAMA, S. et al.: "Urolithiasis in Okinawa, Japan: a relatively high prevalence of uric acid stones". Int. J. Urol. Aug; 10: 411. 2003.

13. MORAN, M.E.: "Uric acid stone disease". Front Biosci Sep; 1, 8, s: 1339;. 2003.

14. KAID-OMAR, Z.; BELOUATEK, A.; DRIOUCH, A. et al.: "Effects of diuretic therapy on spontaneous expulsion of urinary calculi, urinary $\mathrm{pH}$, crystalluria in lithiasic patients". Prog. Urol. Jun; 11: 450. 2001

15. BERG, W.; SCHANZ, H.; EISENWINTER, B. et al.: "The incidence distribution and development of a trend of urinary stone substances. An elevation of the data on over 210,000 urinary stone analyses from the area of the former DDR". Urologe A Mar; 31: 98. 1992. 